\title{
PHYSICAL NATURE OF "ANOMALOUS" ELECTRONS IN HIGH-CURRENT VACUUM DIODES
}

\author{
Vasily Y. Kozhevnikov a , Andrey V. Kozyrev ${ }^{\mathrm{b}}$ \\ Institute of High Current Electronics, Department of Theoretical \\ Physics, Tomsk, Russian Federation \\ a e-mail: Vasily.Y.Kozhevnikov@ieee.org, corresponding author, \\ ORCID iD: (iohttps://orcid.org/0000-0001-7499-0578 \\ b e-mail: kozyrev@to.hcei.tsc.ru, \\ ORCID iD: (i)https://orcid.org/0000-0002-7078-7991
}

DOI: 10.5937/vojtehg69-30116; https://doi.org/10.5937/vojtehg69-30116

FIELD: High-current vacuum electronics

ARTICLE TYPE: Original scientific paper

\section{Abstract:}

Introduction/purpose: A fundamental theoretical explanation is given for the fact that in subnanosecond vacuum diodes there exists a group of electrons with kinetic energies much higher than the applied voltage (multiplied by the value of the elementary charge) $q U_{\text {max. }}$

Methods: A mathematical method is used based on the numerical solution of the Vlasov-Poisson differential equations system for one-dimensional vacuum diodes of various designs.

Results: It is shown in detail that the so-called "anomalous" electrons appear in the transient time domain characterizing the processes of establishing current flow in vacuum diodes.

Conclusion: It has been convincingly shown that the presence of "anomalous" electrons is not associated with either the diode design or the presence of additional current carriers. In vacuum diodes with a subnanosecond leading edge of the voltage pulse, the excess of energy over $q U_{\max }$ can be over $20 \%$.

Key words: numerical simulation, vacuum electronics, vacuum breakdown.

\section{Introduction}

The electrodynamic effects of space-charge limited flows are associated with many interesting phenomena appearing in various fields of applied electrodynamics and electronics. Generally, the space-charge limits (SCL) can be observed in a fairly generalized two-electrode system (diode) to which a certain voltage is applied. By increasing the charges 
injection into the diode, we neglect the electric potential near the emission region bringing the electric field near the zero value. This tendency limits the maximum current that can be carried through the diode.

In the beginning, the SCL effect was studied for the simplest case of a planar one-dimensional vacuum diode (Child, 1911), (Langmuir, 1913). It is known as Child's law

$$
j_{C . L .}=\frac{4 \varepsilon_{0}}{9} \sqrt{\frac{2 q}{m}} \frac{U^{3 / 2}}{D^{2}},
$$

where $U$ - the applied voltage, $D$ - the interelectrode distance, $q$ and $m$ the electron charge and mass, respectively, and $\varepsilon_{0}$ - the vacuum dielectric permittivity.

Although Child's law involves many rough assumptions, it gives a good theoretical framework for understanding the SCL phenomenon and its operating limits. Regarding Child's law, in order to obtain the SCL current value (1), it was assumed that in a planar diode there are only electrons with zero initial velocities. Another important peculiarity of Child's law is that the system was assumed to be in a steady state.

To extend the applicability of Child's law, many theoretical and experimental research studies have been done. The problem of oversimplification was connected to zero initial by accurately taking into the account thermal electron velocities (Langmuir, 1923), (Jaffé, 1944). The extension of a single-species consideration to Child's law showed that adding positive ions weakens the SCL effects (Lin, 2005). Various investigations have been also carried out in order to relax the assumption of one-dimensionality. In this direction, even nontrivial two- and threedimensional cases were treated by using both analytical and numerical computational approaches (Rokhlenko \& Lebowitz, 2007), (Koh et al, 2005).

Overcoming the steady-state assumption is much more difficult from the theoretical point of view. This takes place because the study of diode transient processes requires non-stationary theoretical models or Particle in cell simulations (PIC). In the beginning of the computational physics era, the PIC method allowed studying a large number of transient processes (Birdsall \& Langdon, 1991), including SCL-associated problems for vacuum electronics (Ragan-Kelley et al, 2009), (Griswold et al, 2012). Later, some serious disadvantages of the PIC approach were discovered (Kozhevnikov et al, 2016), (Kozhevnikov et al, 2017), imposing certain restrictions to the solutions of fundamental problems. 
A classical planar vacuum diode and Child's law are nowadays connected with the investigations of high-voltage nanosecond and subnanosecond electronics. As a result, new effects have been discovered experimentally in nanosecond high-current pulsed vacuum electronic diodes. One of them is the effect of fast electron appearance with kinetic energies $\varepsilon>q U_{\max }$ greater than the maximum voltage value $U_{\max }$ being applied to the vacuum diode (multiplied by an elementary charge $q$ ). Such electrons are called electrons having "anomalously high" energies ("anomalous" electrons).

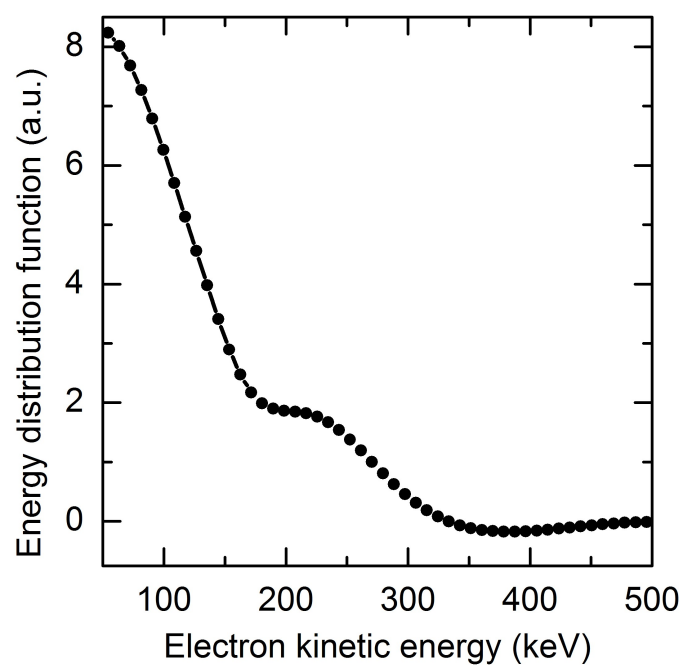

Figure 1 - Experimentally reconstructed fast electron spectrum in the vacuum diode Pис. 1 - Восстановленный экспериментальный спектр быстрых электронов вакуумного диода

Слика 1 - Експериментално реконструисани спектар брзих електрона у вакуумској диоди

Let us consider one of striking experimental examples in which this effect of the appearance of electrons with anomalous energies is observed (Kozyrev et al, 2010). In this experimental paper, a RADAN-220 nanosecond high-voltage generator was attached to an IMAZ-150E vacuum diode in a simple circuit with $20 \Omega$ ballast impedance. The voltage pulse waveform was a trapezium having an amplitude of $250 \mathrm{kV}$ with a total pulse duration equal to $2 \mathrm{~ns}$ and the $0.5 \mathrm{~ns}$ risetime. We reconstructed an energy spectrum by using the Tikhonov regularization routine (Kozyrev et al, 2010) thus obtaining two spectral groups of electrons. This could be seen in Figure 1. The main group represents the 
majority of low-energy electrons with the mean energy values continuously decreasing to $\sim 200 \mathrm{keV}$. The second group is an ensemble of high-energy ("anomalous") electrons with the mean energy maximum around $220 \mathrm{keV}$ and with a long "distribution tail" stretching to $\sim 320 \mathrm{keV}$. Such "anomalous" distributions arise in multiple experiments considering vacuum diodes of different configurations where ultra-short pulses have been applied to them.

Explaining the physical nature of this phenomenon within the framework of the simplified SCL theories is impossible due to their stationarity - "anomalous" electrons do not appear in steady-state current flow regimes. Some theoretical aspects of unsteady current flows in planar vacuum diodes have been studied early (Kadish et al, 1985). Namely, simplified transient models show the existence of relaxation oscillations during the current establishing in the diode. The amplitude of the first oscillation period can be $\sim 2.75$ times greater than the steady-state current value(1). Nevertheless, simplified unsteady current flow theories do not provide the spectral composition of an electron beam reaching the anode.

Here we propose an accurate simulation performed by using the fundamental principles of physical kinetics based on a direct (numerical) solution of the kinetic Vlasov-Poisson system of equations. We show that, in vacuum diodes, the "anomalous" electrons appearance is provoked by the restricted duration of the voltage pulse front. Electrons with "anomalously" high energies are neither a consequence of the cathode plasma existence nor connected to the geometrical peculiarities of diode construction.

\section{Kinetic theoretical model}

As already mentioned above, the theoretical consideration of transient processes in a vacuum diode is based on the solution of a nonstationary kinetic equation, more precisely, the Vlasov-Poisson system of equations for a one-dimensional gap

$$
\left\{\begin{array}{l}
\frac{\partial f}{\partial t}+\frac{p_{x}}{m \gamma\left(p_{x}\right)} \frac{\partial f}{\partial x}-q E_{x} \frac{\partial f}{\partial p_{x}}=0 \\
\frac{\partial^{2} \varphi}{\partial x^{2}}=-\frac{q}{\varepsilon_{0}} \int_{-\infty}^{\infty} f d p_{x}, \quad E_{x}=-\frac{\partial \varphi}{\partial x}
\end{array}\right.
$$

where $f$ - the electron distribution function, $x$ - the coordinate, $t$ - time, $\varphi$ - the electrostatic potential, $E_{x}-$ a component of the electrostatic field, 
and $\gamma$ - the relativistic factor. It should be mentioned that a planar onedimensional vacuum diode is considered here. That is done intentionally in order to get rid of probable geometrical pecularities affecting the current flow in the Child's vacuum diode.

One-dimensionality significantly simplifies the problem because Poisson's equation in (2) can be solved in quadratures, so the exact solution is represented as follows

$$
\begin{aligned}
& E_{x}(x, t)=-\frac{q}{\varepsilon_{0}} \int_{0}^{x} \int_{-\infty}^{\infty} f\left(x, p_{x}, t\right) d p_{x} d x- \\
& -\frac{U(t)}{D}+\frac{q}{\varepsilon_{0} D} \int_{0}^{D} \int_{0}^{x^{\prime}} \int_{-\infty}^{\infty} f\left(x, p_{x}, t\right) d p_{x} d x^{\prime} d x .
\end{aligned}
$$

where $U(t)$ - the anode potential.

The boundary and initial conditions for the Vlasov equation have been chosen according to those in previous papers (Kozhevnikov et al, 2016, Kozhevnikov et al, 2017). The numerical simulation starts with an empty gap (i.e. $f=0$ ). In the cathode, we maintain the electron emission where the electron distribution function is assumed to be Maxwellian.

The solution of the Vlasov equation has been obtained using the numerical so-called semi-Lagrangian methods. In order to perform the numerical solution accurately, the cubic spline interpolation scheme (Cheng \& Knorr, 1976) was used. To validate the numerical solution, the PIC4 high-precision numerical scheme was also used (Umeda et al, 2012). Both numerical schemes were implemented on the uniform 5,000 by 10,000 elements phase space grid to provide a high accuracy of numerical computations. On the basis of the result of the joint numerical solution procedure for the Vlasov-Poisson system of equations (2), we obtain the electron distribution function $f\left(x, p_{x}, t\right)$ and compute the collector (anode) current density for each simulation time-step

$$
j(t)=-\frac{q}{m} \int_{-p_{\max }}^{p_{\max }} \frac{p_{x}}{\gamma\left(p_{x}\right)} f\left(x=D, p_{x}, t\right) d p
$$

where $p_{\max }$ is the largest available momentum in the computational scheme. All numerical integrals, e.g. (4), have been computed using the Simpson integration rule. Also, the seven-point Savitzky-Golay filtering (Savitzky \& Golay, 1964) was used to perform smoothing of the anode 
voltage waveform front edge. The numerical algorithm was implemented in the Mathworks MATLAB system using the computation functionality of the Nvidia CUDA GPU graphics subsystem.

\section{Results of the numerical simulation}

Let us consider a planar vacuum diode having the following parameters: $D=1 \mathrm{~cm}$ and $U_{\max }=2 \mathrm{kV}$. It turns to be nonrelativistic, so one can assume the relativistic factor to be $\gamma \sim 1$. At the cathode, we take an average electron density to be around $\sim 1.5 \cdot 10^{18} \mathrm{~m}^{-3}$ and thermal spread $\sim 1 \mathrm{eV}$. For these values, the emission current value is much higher than Child's value (1), so the cathode can be assumed to have unrestricted emission capability.

In the following plot (Figure 2), we compare three diode current density time profiles given for different values of risetime. For the same Umax, we take the quasi-stationary risetime value $\sim 1 \mathrm{~ns}$, i.e. compared to the simulation end time ( $5 \mathrm{~ns}$ ), as well as subnanosecond risetime value $\sim 0.1 \mathrm{~ns}$ and the intermediate value $\sim 0.5 \mathrm{~ns}$. We can easily notice that the current density profiles significantly differ. Long (quasi-stationary) risetime leads to a slow growth of a collector current to the value equal to Child's law (1). We get a completely contrasting situation if the risetime is much less than one nanosecond. In this case, the emergence of relaxation oscillations can be seen in the transition region. The maximum amplitude of relaxation oscillations significantly exceeds the Child's value (1). In all three cases of the calculation presented in Figure 2, the diode (collector) current finally reaches the values equal to (1). Also, there is a time delay between $t=0$ and the time point of non-zero collector current. This time delay determines an instant from which the electron beam reaches the anode (collector).

After reaching the anode, relaxation oscillations of the current begin. It can be noted that the higher their amplitude is, the faster the anode potential changes, i.e. risetime. The increased nonstationarity in the transition region leads to the fact that in the gap there are space charge oscillations. They are associated with a sharp decrease in the charge in the gap when the beam reaches the anode and with a subsequent increase in the current extraction from the cathode. Further on, the process goes in waves up to the moment of a steady current flow. 


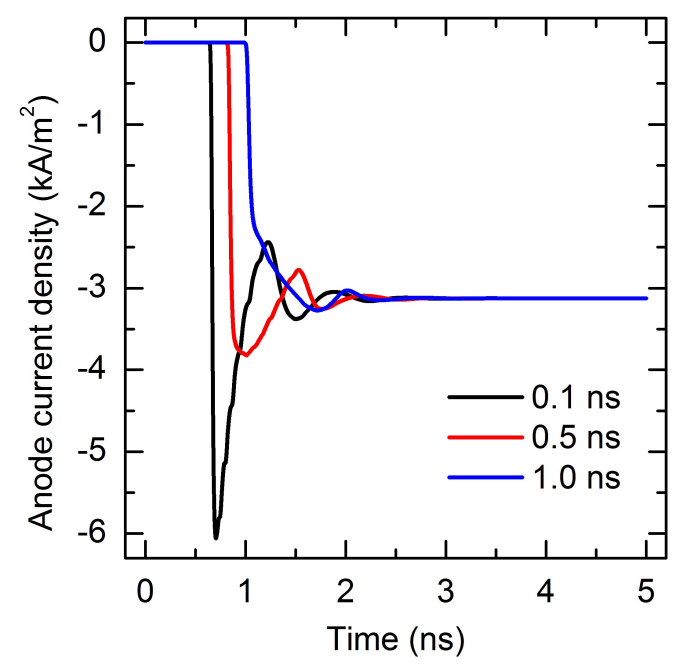

Figure 2 - Time profiles of the diode current density given at various risetimes Puс. 2 - Временные профили плотности тока диода при различных временах нарастания

Слика 2 - Временски профрили густине струје диоде у различитим временима pacma

A more particular case of the formation of a sharp surge in the collector current in a planar vacuum diode with an "instantaneous" supply of the anode potential has already been considered in the literature (Kadish et al, 1985). However, due to the use of the simplified transition region theory, the authors of early works did not clarify the velocity distribution of electrons, which "deliver" the maximum amplitude of relaxation oscillations of the collector current density to the anode. Our theoretical model is based on the use of the evolution of the electron distribution function; therefore, it allows one to fix instantaneous velocity distributions at any spatial point.

Figures 3, 4 and 5 show the density plots of the electron distribution function at times that approximately correspond to those time points at which (for risetime $\sim 0.1 \mathrm{~ns}$ ) the maxima of collector current density relaxation oscillations are formed. The highest collector current is achieved at $t=0.7 \mathrm{~ns}$ (Figure 3 ), the next point of the oscillation period corresponds to $t=1.5$ ns (Figure 4 ). In Figure 5 , the phase portrait of the distribution function is shown, corresponding to the diode current steady state at $t=4 \mathrm{~ns}$, where the relaxation oscillations are completely damped. 


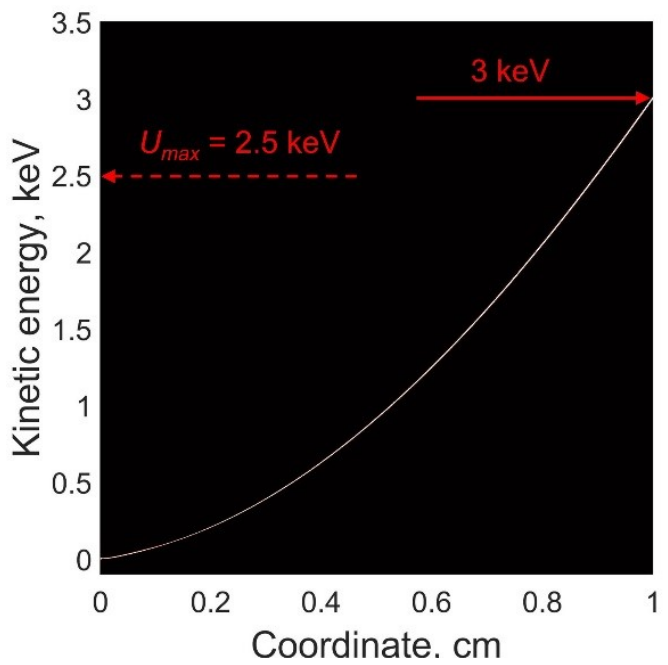

Figure 3 - Electron distribution function density plot at $0.7 \mathrm{~ns}$

Puc. 3 - Грасрик плотности фрункции распределения электронов при 0.7 нс Слика 3 - Графрикон густине функције расподеле електрона на 0,7 нс

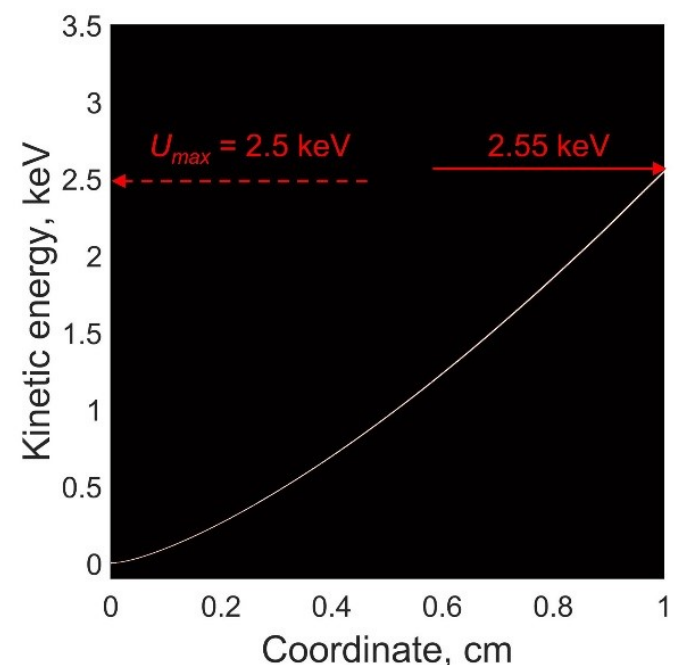

Figure 4 - Electron distribution function density plot at 1.5 ns

Puc. 4 - Графрик плотности функции распределения электронов при 1.5 нс Слика 4 - Графрикон густине функције расподеле електрона на 1,5 нс 


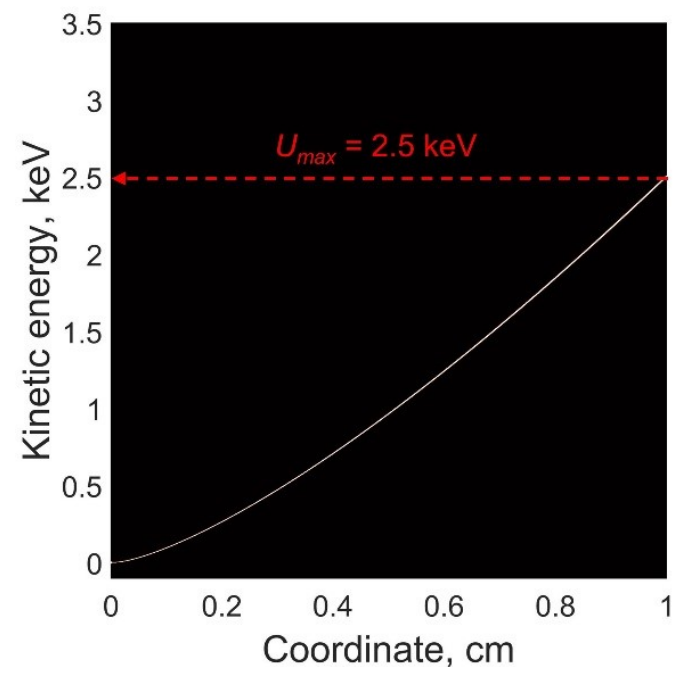

Figure 5 - Electron distribution function density plot at 4 ns (steady-state current flow regime)

Puc. 5 - Графрик плотности фрункции распределения электронов при 4 нс (режим установившегося токопротекания)

Слика 5 - Графрикон густине фрункције расподеле електрона на 4 нс (стационарни ток струје)

Three figures above demonstrate the essence of the physical effect discovered by various researchers in series of experimental studies. In a nonstationary rapidly changing electromagnetic field, the transport of charged particle beams (for example, an electron beam in a planar vacuum diode) is always affected by space charge oscillations. This effect is interrelated with the acceleration of charges to kinetic energies exceeding the value of the instantaneously "applied voltage" (multiplied by elementary charge). Such phenomena are typical for physical situations where charged particles interact with an electric field of the "traveling wave" type (Kozyrev et al, 2018).

In Figure 3, the average value of the energy of the electron beam arriving at the anode is $3 \mathrm{keV}$ with the maximum amplitude of the anode potential equal to $2.5 \mathrm{kV}$. This excess of the anode potential is about $20 \%$. The theory convincingly indicates that it is the "anomalous" electrons that form the peak of the collector current's relaxation oscillations in the diode operating in the subnanosecond mode. For a diode with a prolonged (over $1 \mathrm{~ns}$ ) risetime, the phase portrait of the distribution function does not contain an "anomalous" energy component and is similar to a stationary current flow (in Figure 5). The integral 
spectrum of the beam, i.e. of the electrons falling on the collector will be mainly represented by the $2.5 \mathrm{keV}$ maximum, since the relative fraction of "anomalous" electrons for a diode operating in a steady-state current flow mode is negligible.

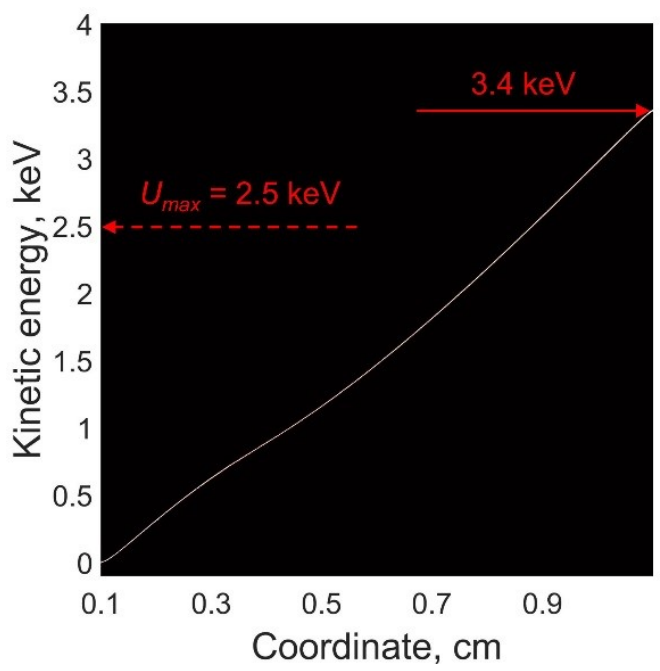

Figure 6 - Electron distribution function density plot at $0.5 \mathrm{~ns}$ for the axially-symmetric vacuum diode

Puc. 6 - Графрик плотности фрункции распределения электронов в осесимметричном вакуумном диоде при 0.5 нс

Слика 6 - Графрикон густине функције расподеле електрона у осносиметричној вакуумској диоди на 0,5 нс

The planar diode was deliberately taken in order to demonstrate that the appearance of "anomalous" electrons is not related to the peculiarities of the diode geometry. Most often, experimental diodes are a cathode with a small radius of curvature and a relatively "flat" anode. Because of this fact, the existence of "anomalous" electrons was mistakenly associated with the fact that the electric field strength near the cathode is much stronger than the near-anode one.

In fact, the presence of spatial non-uniformities leads to an increase in the relative fraction of electrons with "anomalous" energies. In order to demonstrate this effect, a simulation of an axisymmetric vacuum diode was performed. The design of the electrodes consisted of two coaxial cylinders (the cathode is inside). The interelectrode gap was $1 \mathrm{~cm}$, the cathode radius was $1 \mathrm{~mm}$, and the anode was $11 \mathrm{~mm}$. The amplitude of the anode voltage was chosen to be similar $-2.5 \mathrm{kV}$. The voltage rise time was $0.1 \mathrm{~ns}$. With these parameters, as in the previous case, 
relaxation oscillations of the collector current were observed. The maximum amplitude of the oscillations occurred at a time instant of $0.5 \mathrm{~ns}$. At a given time, the electron distribution function density plot is given in Figure 6. It can be seen that, at this time point, the average energy of the electron beam is $3.4 \mathrm{keV}$, which is $36 \%$ higher than the voltage across the diode.

\section{Conclusions}

In this paper, we have convincingly shown that "anomalous" electrons (with kinetic energies $\varepsilon>q U_{\max }$ ) always arise in the transient mode of a vacuum diode. Modeling convincingly shows that the source of these "anomalous" electrons in vacuum diodes is not connected with any specific diode design, alternative cathode emission mechanism, or the presence of other charge carriers in the gap (for example, positive ions). The reason for the appearance of "anomalous" electrons is directly related to the process of buildup of relaxation oscillations of the space charge; the more intense it is, the shorter risetime the anode voltage pulse has.

\section{Special acknowledgment}

This paper is dedicated to the blessed memory of the choir conductor, head of the Department of Choral Conducting, the honored professor of Tomsk State University - Vitaly Sotnikov (1939-2020). The authors express their sincere gratitude to doctors and nurses around the world, the people who found the strength to fight COVID-19, not sparing their health and lives for the sake of defeating the pandemic for the benefit of all mankind.

\section{References}

Birdsall, C.K. \& Langdon, A.B. 1991. Plasma Physics via Computer Simulation. Boca Raton: CRC Press. Available at: https://doi.org/10.1201/9781315275048. ISBN: 9781315275048.

Cheng, C.Z. \& Knorr, G. 1976. The integration of the vlasov equation in configuration space. Journal of Computational Physics, 22(3), pp.330-351. Available at: https://doi.org/10.1016/0021-9991(76)90053-X.

Child, C.D. 1911. Discharge From Hot CaO. Physical Review (Series I), 32(5), pp.492-511. Available at: https://doi.org/10.1103/PhysRevSeriesl.32.492.

Griswold, M.E., Fisch, N.J. \& Wurtele, J.S. 2012. Amended conjecture on an upper bound to time-dependent space-charge limited current. Physics of Plasmas, 19(2), art.number:024502. Available at: https://doi.org/10.1063/1.3671961. 
Jaffé, G., 1944. On the Currents Carried by Electrons of Uniform Initial Velocity. Physical Review, 65(3-4), pp.91-98. Available at: https://doi.org/10.1103/PhysRev.65.91.

Kadish, A., Peter, W. \& Jones, M.E. 1985. A Generalization of the ChildLangmuir Relation for One-Dimensional Time-Dependent Diodes. IEEE Transactions on Nuclear Science, 32(5), pp.2576-2578. Available at: https://doi.org/10.1109/TNS.1985.4333985.

Koh, W.S., Ang, L.K. \& Kwan, T.J.T. 2005. Three-dimensional ChildLangmuir law for uniform hot electron emission. Physics of Plasmas, 12(5), art.number:053107. Available at: https://doi.org/10.1063/1.1913612.

Kozhevnikov, V.Y., Kozyrev, A.V. \& Semeniuk, N.S. 2016. Kinetic modelling of the one-dimensional planar virtual cathode oscillator. In: 24th Telecommunications Forum (TELFOR), Belgrade, pp.1-4, November 22-23. Available at: https://doi.org/10.1109/telfor.2016.7818844.

Kozhevnikov, V.Y., Kozyrev, A.V. \& Semeniuk, N.S. 2017. Modeling of Space Charge Effects in Intense Electron Beams: Kinetic Equation Method Versus PIC Method. IEEE Transactions on Plasma Science, 45(10), pp.27622766. Available at: https://doi.org/10.1109/tps.2017.2726501.

Kozyrev, A.V., Kozhevnikov, V.Yu., Baksht, E.Kh., Buranchenko, A.G. \& Tarasenko, V.F. 2010. Spectrum reconstruction of a nanosecond electron beam from the data on its extinction in thin foils. Russian Physics Journal, 53(4), pp.361-368. Available at: https://doi.org/10.1007/s11182-010-9430-1.

Kozyrev, A., Kozhevnikov, V. \& Semeniuk, N. 2018. Why do Electrons with "Anomalous Energies" appear in High-Pressure Gas Discharges? In: Torrisi, L. \& Cutroneo, M. (Eds.) EPJ Web of Conferences, 167, art.number:01005. Available at: https://doi.org/10.1051/epjconf/201816701005.

Langmuir, I. 1913. The Effect of Space Charge and Residual Gases on Thermionic Currents in High Vacuum. Physical Review, 2(6), pp.450-486. Available at: https://doi.org/10.1103/physrev.2.450.

Langmuir, I. 1923. The Effect of Space Charge and Initial Velocities on the Potential Distribution and Thermionic Current between Parallel Plane Electrodes. Physical Review, 21(4), pp.419-435. Available at: https://doi.org/10.1103/physrev.21.419.

Lin, M-C. 2005. Space-charge effects of electrons and ions on the steady states of field-emission-limited diodes. Journal of Vacuum Science \& Technology B: Microelectronics and Nanometer Structures, 23(2), art.number:636. Available at: https://doi.org/10.1116/1.1875352.

Ragan-Kelley, B., Verboncoeur, J. \& Feng, Y. 2009. Two-dimensional axisymmetric Child-Langmuir scaling law. Physics of Plasmas, 16(10), art.number:103102. Available at: https://doi.org/10.1063/1.3243474.

Rokhlenko, A. \& Lebowitz, J.L. 2007. Space-charge-limited, twodimensional unmagnetized flow in a wedge geometry. Journal of Applied Physics, 102(12), art.number:123307. Available at: https://doi.org/10.1063/1.2822471. 
Savitzky, A. \& Golay, M.J.E. 1964. Smoothing and Differentiation of Data by Simplified Least Squares Procedures. Analytical Chemistry, 36(8), pp.16271639. Available at: https://doi.org/10.1021/ac60214a047.

Umeda, T., Nariyuki, Y. \& Kariya, D. 2012. A non-oscillatory and conservative semi-Lagrangian scheme with fourth-degree polynomial interpolation for solving the Vlasov equation. Computer Physics Communications, 183(5), pp.1094-1100. Available at: https://doi.org//10.1016/j.cpc.2012.01.011.

ФИЗИЧЕСКАЯ ПРИРОДА «АНОМАЛЬНЫХ» ЭЛЕКТРОНОВ В СИЛЬНОТОЧНЫХ ВАКУУМНЫХ ДИОДАХ

Василий Ю. Кожевников, корресподент, Андрей В. Козырев

Институт сильноточной электроники, Лаборатория теоретической физики, г. Томск, Российская Федерация

РУБРИКА ГРНТИ: 29.00.00 ФИЗИКА:

29.27.00 Физика плазмы;

29.27.47 Численные методы в физике плазмы

ВИД СТАТЬИ: оригинальная научная статья

Резюме:

Введение/цель: Дается фундаментальное теоретическое объяснение тому факту, что в субнаносекундных вакуумных диодах существует группа электронов с кинетической энергией, намного превышающей приложенное напряжение (умноженное на величину элементарного заряда) $q U_{\max }$

Методы: Используется математический метод, основанный на численном решении системы диффреренциальных уравнений Власова-Пуассона для одномерных вакуумных диодов различной конструкции.

Результаты: Подробно показано, что так называемые «аномальные» электроны появляются в переходной временной области, характеризующей процессы установления протекания тока в вакуумном диоде.

Выводы: Убедительно показано, что наличие «аномальных» электронов не связано ни с конструкцией диода, ни с наличием дополнительных носителей тока. $B$ вакуумных диодах $c$ субнаносекундным передним фронтом импульса напряжения превышение энергии над $q U_{\max }$ может составлять более $20 \%$.

Ключевые слова: численное моделирование, вакуумная электроника, вакуумный пробой. 


\section{ФИЗИЧКА ПРИРОДА „АНОМАЛНИХ” ЕЛЕКТРОНА У ВИСОКО- ВАКУУМСКИМ ДИОДАМА}

Василиј Ј. Кожевников, аутор за преписку, Андреј В. Козирев

Институт високе струје, Лабораторија за теоријску физику,

Томск, Руска Федерација

ОБЛАСТ: фризика плазме

ВРСТА ЧЛАНКА: оригинални научни рад

\section{Сажетак:}

Увод/циљ: Рад даје основно теоријско објашњење чињенице да у субнаносекундним вакуумским диодама постоји група електрона са кинетичком енергијом много већом од примењеног напона (помноженог са елементарним наелектрисањем) $q U_{\text {max. }}$

методе: Примењена је математичка метода заснована на нумеричком решењу система диференцијалних једначина Власов-Поисон за једнодимензионалне вакуумске диоде различитог дизајна.

Резултати: Детаљно је приказано да се у прелазном временском домену појављују такозвани „аномални” електрони, uто карактерише процесе успостављања струјног тока у вакуумској диоди.

Закључак: Доказано је да присуство „аномалних” електрона није повезано ни са дизајном диоде, ни са присуством додатних носача струје. У вакуумским диодама са субнаносекундном предњом ивицом импулса напона вишак енергије преко $q \cup_{\max }$ може бити већи од $20 \%$.

Кључне речи: нумеричка симулација, вакуумска електроника, вакуумски пробој.

Paper received on / Дата получения работы / Датум пријема чланка: 30.12.2021.

Manuscript corrections submitted on / Дата получения исправленной версии работы / Датум достављања исправки рукописа: 25.01.2021.

Paper accepted for publishing on / Дата окончательного согласования работы / Датум коначног прихватања чланка за објављивање: 27.01.2021.

(c) 2021 The Authors. Published by Vojnotehnički glasnik / Military Technical Courier

(www.vtg.mod.gov.rs, втг.мо.упр.срб). This article is an open access article distributed under the terms and conditions of the Creative Commons Attribution license

(http://creativecommons.org/licenses/by/3.0/rs/).

() 2021 Авторы. Опубликовано в «Военно-технический вестник / Vojnotehnički glasnik / Military Technical Courier» (www.vtg.mod.gov.rs, втг.мо.упр.срб). Данная статья в открытом доступе и распространяется в соответствии с лицензией «Creative Commons» (http://creativecommons.org/licenses/by/3.0/rs/).

(C) 2021 Аутори. Објавио Војнотехнички гласник / Vojnotehnički glasnik / Military Technical Courier (www.vtg.mod.gov.rs, втг.мо.упр.срб). Ово је чланак отвореног приступа и дистрибуира се у складу са Creative Commons лиценцом (http://creativecommons.org/licenses/by/3.0/rs/).

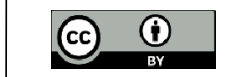

